\title{
Wyreżyserować lekcję Nauczyciel jako aktor, reżyser i mistrz
}

\author{
To direct a lesson \\ Teacher as an actor, director and masters
}

Summary: The article's aim is to compare the specificity of two theoretically quite remote professions - that of a film director and a teachers. The analysis of differences and convergence points of the said jobs is to capture and particularise the potential of their mutual inspiration. What constitutes the exemplary material around which the presented research revolves are: the elements of the school didactic-upbringing process, work with film crew, and producing and theatrical play. Significant reference points for the analysis were the greatest role models in the field of pedagogics and film directing.

Keywords: teacher, film director, didactics, film, theatre

Nie ulega wątpliwości, że nauczyciel jest przede wszystkim aktorem ${ }^{1}$ Każda z lekcji to jego specyficzny performans wykonywany przed wymagającą i krytyczną widownią. Kształt takiego spektaklu czy jak chciał Jan Nowakowski — „widowiska"2 każdorazowo zależy od wielu czynników, począwszy

${ }^{1}$ Koncepcję tę podejmowało już wielokrotnie wielu badaczy, np. w książce A. Janowski: Uczeń w teatrze życia szkolnego. Warszawa 1995, czy P. Mikiewicz: Nauczyciel jako istotny aktor społecznego świata szkoły $\mathrm{w}$ artykule zamieszczonym w wydawnictwie monograficznym: Nauczyciel: misja czy zawód? Społeczne i profesjonalne aspekty roli. Red. P. Rudnicki, B. Kutrowska, M. Nowak-Dziemianowicz. Wrocław 2008.

${ }^{2}$ Nauczyciel miałby być aktorem i reżyserem ,skomponowanej przez siebie lekcji, tego »widowiska«, o którym tu orzekano, iż może mieć w sobie coś fascynującego". J. Nowakowski: Moment twórczy w nauczaniu literatury. „Dydaktyka Literatury” 1982, t. 5, s. 12. 
od tekstu scenicznego (omawiany na lekcji materiał) przez zebranych widzów (zespół klasowy wraz ze szczególnymi uwarunkowaniami³) do możliwości aktorskich nauczyciela (zręczności w przekazaniu materiału lekcyjnego) ${ }^{4}$. Model współpracy na linii aktor - publiczność będzie wypadkową potencjału improwizacyjnego uczniów (chęci niezależnego włączenia się w proces) i koncepcji nauczyciela (,,pomysłu” na lekcję).

Wspomniana na ostatnim miejscu koncepcja lekcyjna jest częścią drugiej, może ważniejszej „roli”, jaką do odegrania na lekcji ma nauczyciel. Chodzi oczywiście o rolę reżysera jednostki lekcyjnej. W pracach naukowych z obszaru szeroko pojętej pedagogiki zawody reżysera i nauczyciela są z sobą okazjonalnie zestawiane ${ }^{5}$, ale punkt widzenia, który wspomniane teksty przyjmują, nie pozwala na szerszą analizę wielopoziomowego charakteru pracy reżysera. Niniejszy artykuł, będący efektem doświadczeń pedagogiczno-reżyserskich piszącego, ma na celu zarysowanie perspektyw wzajemnych inspiracji wspomnianych profesji na podstawie równoległej analizy należnych im „elementów składowych". Na taki sposób ujęcia tematu pozwoli potraktowanie (za Janem Nowakowskim) szkolnej lekcji jako specyficznego, niepochwytnego, nieodwracalnego, rozwijającego się w czasie dzieła sztuki, na wzór filmu lub dramatú ${ }^{6}$. Dla lepszego zobrazowania wybranych aktorskich i reżyserskich komponentów profesji nauczyciela zostanie przywołana również scena lekcji języka angielskiego z filmu Petera Weira Stowarzyszenie Umartych Poetów ${ }^{7}$ (na podstawie powieści Nancy H. Kleinbaum o tym samym tytule), w którym w rolę charyzmatycznego, a zarazem inspirującego pedagoga Johna Keatinga wcielił się Robin Williams.

Użycie słowa profesja do scharakteryzowania omawianych w artykule zawodów jest intencjonalne. $\mathrm{Z}$ jednej strony ma zerwać ze społecznym utożsamianiem pracy nauczyciela tylko i wyłącznie z przyjemnością lub pracą dla idei $^{8}$, z drugiej strony ma na celu podkreślenie konieczności profesjonalnego

${ }^{3}$ Wiele czynników, które mają wpływ na nastrój panujący w klasie.

4 Stanisław Bortnowski pisał: „Energia i słabość to stałe wyznaczniki pracy nauczycielskiej, zarazem reżyserskiej i aktorskiej, a nasz stan ducha jest nieodłącznym elementem psychologii lekcji [...]". S. Bortnow ski: Przewodnik po sztuce uczenia literatury. Warszawa 2005, s. 109.

${ }^{5}$ Między innymi w pracach: Stanisława Bortnowskiego, Jana Nowakowskiego, Małgorzaty Taraszkiewicz czy Marka Pieniążka.

${ }^{6}$,Jeśli lekcja należy do »sztuki«, to do sztuki rozwijającej się w czasie — jak muzyka, poezja, film, dramat. Jest czymś w istocie swej niepochwytnym, nieodwracalnym, czymś przemijającym. [...] »wibruje«, przekształca się, oddala i znów przybliża się do pierwotnego wyobrażenia w świadomości twórcy, by ostatecznie stać się tym, co może być uznane za dość wierną transpozycję koncepcji pierwotnej — albo też za twór nowy, czasem nieoczekiwany”. J. Nowakowski: Moment sztuki w nauczaniu literatury..., s. 14.

7 Stowarzyszenie umarlych poetów (Dead Poets Society). Reż. P. Weir. USA 1989.

${ }^{8}$ W tym kontekście o zawodzie nauczyciela pisał Stanisław Bortnowski: „Po prostu niech to będzie dobry, atrakcyjny, wymagający pomysłowości, trochę aktorski, trochę reżyserski zawód, 
podejścia do procesu dydaktycznego, jeżeli ma on być efektywny ${ }^{9}$. Znaczącym faktem, który również dobrze oddaje specyfikę przywołanych zawodów, jest to, że z całą pewnością zamiast określenia profesja można by w tytule tego artykułu użyć słowa: powołanie.

\section{Profesjonalizm i powołanie}

Według Wielkiego słownika języka polskiego, słowo profesja oznacza ,zajęcie, którego ktoś się nauczył, by potem wykonywać je jako swoją pracę"10. Tytuł zawodowy zarówno nauczyciela, jak i reżysera można otrzymać, kończąc odpowiednie szkoły. Powszechnie wiadomo jednak, że funkcjonowanie w ramach wspomnianych zawodów nie polega wyłącznie na wykonywaniu przećwiczonych schematów. W ramach studiów pedagogicznych czy reżyserskich młody człowiek otrzymuje jedynie pakiet narzędzi mających potencjalnie pomóc mu się odnaleźć w zawodzie. To, czy stanie się „dobrym” pedagogiem czy reżyserem, nie zależy (w odniesieniu do nauczyciela — dość paradoksalnie) od stopnia wykształcenia, ale przede wszystkim jego cech indywidualnych. Jak pisał Stefan Szuman w artykule Talent pedagogiczny, „Prawdopodobnie nie ma zalet i cnót, których nie należałoby życzyć »nauczycielowi doskonałemu«"11. Stanisław Bortnowski, próbując dookreślić cechy idealnego pedagoga ${ }^{12}$, skonstatował, że próba zebrania wszystkich wymienionych przez teoretyków dydaktyki właściwości wyróżniających dobrego nauczyciela ,prowadzi donikąd i [...] tworzy nierealną i bezładną wizję"13. Zbiorczym hasłem, w którym często „zawiera się” sedno bycia dobrym nauczycielem, jest słowo talent bądź powo-

daleki od monotonii i nudy, prawnie chroniony i materialnie dowartościowany”. S. Bortnowski: Przewodnik po sztuce uczenia literatury..., s. 30.

${ }^{9}$ Warto już w tym miejscu zaznaczyć (poddając się żywiołowi językowych skojarzeń), że w obu profesjach niejednokrotnie efektywność łączy się z efektownością. Efektowny spektakl czy film przynosi radość widzowi, tak samo jak efektowna (interesująca, zaskakująca) lekcja uczniowi.

${ }_{10}$ Zawód [hasło]. W: Wielki słownik języka polskiego. Red. P. Żmigrodzki. https://wsjp. pl/index.php?id_hasla=35176\&id_znaczenia $=3972763 \& 1=21 \& i n d=0$ [data dostępu: 12.12 .2019 ].

${ }^{11}$ S. Szuman: Talent pedagogiczny. W: Osobowość nauczyciela. Red. W. Okoń. Warszawa 1962, s. 95.

12 „Dobry nauczyciel kieruje się miłością do ludzi: zarówno dorosłych, jak i dzieci (Dawid), ma dar kontaktowości (Mysłakowski), postępuje etycznie, jest uczciwy i pracowity (Kreutz), ma zapał i chęć do pracy zawodowej (Kozłowski)". S. Bortnowski: Przewodnik po sztuce uczenia literatuy..., s. 20.

${ }^{13}$ Ibidem. 
tanie $^{14}$. Bez wątpienia, większość z czytających te słowa potrafiłoby wymienić co najmniej kilku znanych mu przedstawicieli omawianych tu profesji, którzy, mimo przyswojonej wiedzy i ukończonych studiów, sprawiali wrażenie, jak gdyby „zupełnie minęli się z powołaniem”.

To właśnie słowo przychodzi na myśl, kiedy czyta się rozmaite wywiady $\mathrm{z}$ uznanymi reżyserami. Wiele z historii będących odpowiedzią na najbardziej znienawidzone przez twórców filmowych pytanie: ,jak się zaczęła pana/pani przygoda z kinem?" stało się już niemal mitami, które sugerują słuchaczowi, że po prostu „tak musiało być”. Zdaje się, że pracujący jako nastolatek w wypożyczalni kaset VHS Quentin Tarantino nie miał innej możliwości, jak tylko zostać jednym z najbardziej cenionych współczesnych reżyserów ${ }^{15}$. Podobnie żyjące legendy kina - Martin Scorsese ${ }^{16}$ i Roman Polański ${ }^{17}$, którzy uczyli się życia i świata, spędzając czas w kinie, bo tylko do takiej edukacji mieli dostęp. Andrzej Żuławski, zestawiając swoje podejście do twórczości artystycznej z postawą Wernera Herzoga, mówił natomiast: ,[...] on bardziej żyje po to, aby robić filmy, a ja bardziej robię filmy po to, żeby żyć"18. Naturalnie, w podobnej aurze i determinizmie zanurzone są historie/życiorysy nie tylko spełnionych reżyserów, ale również tych, którzy odnosili sukcesy w pracy artystycznej. Dyskurs ten jest najprawdopodobniej efektem przekonania o niepowszednich przymiotach, jakimi są obdarzeni wybitni artyści, a także wynikać może ze swoistości tajemniczej i skomplikowanej materii, w której pracują osoby „powołane" do tworzenia czegoś, czego nadal nie potrafimy w satysfakcjonujący sposób zdefiniować — sztuki. Warto zauważyć, że oprócz artystów najmocniej łączeni z kategorią powołanie są (oprócz, rzecz jasna, mających odbyć przymusową służbę wojskową będącą „powołaniem” zgoła innego rodzaju) duchowni

${ }^{14} \mathrm{~W}$ tym wypadku chodzi o „powołanie” zgodne z potocznym rozumieniem terminu, kojarzące życiowy wybór profesji z tajemnicą i metafizyką. Należy jednak zaznaczyć, że owo pojęcie wielokrotnie było przedmiotem naukowych roztrząsań. Nauczycielskie powołanie definiował na przykład Jan Władysław Dawid jako „miłość dusz ludzkich”. Jak przekonywała Katarzyna Dormus w artykule $O$, duszy nauczycielstwa” w świetle wspomnień gimnazjalistów galicyjskich, „Jest to według niego miłość, bo »człowiek wychodzi poza siebie«, troszcząc się bezinteresownie o drugiego i jest to miłość dusz, bo przedmiotem jej jest dobro moralne i oświecenie drugiej osoby”. K. Dormus: $O$ „,duszy nauczycielstwa” $w$ świetle wspomnień gimnazjalistów galicyjskich. W: Wychowawca, nauczyciel, mistrz. O potrzebie madrości, autorytetu i cnoty. Red. B. Jędrychowska. Wrocław 2017, s. 123.

${ }_{15}$ Zob. M. Górna: Czekacie na nowego Tarantino? Ten facet z wypożyczalni VHS zmienit kino. I wielu próbuje go naśladować. „Gazeta Wyborcza” z 16.08.2019. https://wyborcza. p1/7,101707,25081465, byc-jak-quentin-tarantino-czyli-kto-tu-kopiuje-kogo-jak-facet.html [data dostępu: 13.01.2020].

16 Zob. J. Wróblewski: Reżyserzy. Inowrocław 2013, s. 263.

17 J. Makowska, T. Knittel: Roman Polański. Rozmowy poszczególne. https://ninateka.pl/ film/roman-polanski-cz1 [data dostępu: 5.01.2020].

18 J. Wróblewski: Reżyserzy..., s. 118. 
i nauczyciele. Trudno bowiem zdefiniować, czym tak naprawdę zajmuje się nauczyciel $^{19}$. Jasne jest jednak, że jeżeli robi „to” dobrze — trudno jego szczególne umiejętności przeoczyć.

Czesław Banach w definicji hasła „nauczyciel” zamieszczonego w Encyklopedii pedagogicznej XXI wieku zwraca uwagę, że współczesny nauczyciel powinien odznaczać się profesjonalizmem ${ }^{20}$. Przywołanie tej wartości pozwala na teoretyczne umocowanie efemerycznej istoty tego zawodu w realnych działaniach, jednym słowem — „sprowadza” go ze „świata idei” (i „powołań”) na ziemię. Tak jak reżyser, nauczyciel posługuje się rozmaitymi środkami po to, żeby na swoich odbiorców wpływać, wywołując określone skutki, przede wszystkim edukować ${ }^{21}$. Elżbieta Buchcic definiuje ,profesjonalnego nauczyciela” jako „osobę, która »nie popada w rutynę pracy w szkole«, a wręcz przeciwnie - mimo zmian zachodzących w placówkach edukacyjnych potrafi zainteresować nauczanym przedmiotem"22. Pedagog pracujący nieefektownie ${ }^{23}$ będzie nieefektywny. Uczniowie przestaną go słuchać, stracą do niego sympatię i zaufanie, nie będą brać czynnego udziału w lekcjach, zaczną ich unikać. Co ciekawe, podobnie jest z reżyserem. Jeżeli jego filmy nie spełniają filmo-

19 Potwierdzeniem tezy o „tajemniczej i skomplikowanej materii”, z którą tak jak artysta pracuje nauczyciel, może być koncepcja twórczyni pedagogiki specjalnej w Polsce - Marii Grzegorzewskiej, przekonującej w Listach do młodego nauczyciela z 1946 roku, że dobry nauczyciel „Im jest lepszym człowiekiem, lepiej do pracy przygotowanym, im ma większą dla drugich życzliwość, głębszą o nich troskę i poczucie odpowiedzialności za swoją pracę, tym głębszy zostawi ślad w duszach dzieci”. M. Grzegorzewska: Listy do młodego nauczyciela. Warszawa 1947, s. 15.

${ }^{20}$ Zob. C. Banach: Nauczyciel. W: Encyklopedia pedagogiczna XXI wieku. T. 3. Red. T. Pilch. Warszawa 2004, s. 548.

${ }^{21}$ Dobrym przykładem takiego profesjonalnego podejścia są wytyczne Zenona Klemensiewicza z 1964 roku: „Żadne ogniwo lekcji nie może być czymś przypadkowym w danym miejscu jej budowy i w danym momencie jej trwania; każda czynność i każde pytanie, każda odpowiedź musi mieć swoje uzasadnienie, i to właśnie w tym, a nie w innym kontekście, $w$ tej, a nie innej sytuacji. Lekcja powinna przynieść wyniki, i to właśnie te, dla których nauczyciel je podjął, które sobie z góry ustalił i określił”. Z. Klemensiewicz: Sposoby wprowadzenia, opracowania i utrwalenia nowego materiału. W: Wybór prac z metodyki nauczania języka polskiego. Red. B. Wieczorkiewicz. Warszawa 1964, s. 68.

${ }^{22}$ E. Buchcic: Czynniki warunkujace profesjonalizm nauczyciela. „Prace Naukowe Akademii im. Jana Długosza w Częstochowie" 2016, nr 2 (t. 25), s. 49.

${ }^{23}$ Podobnie jak zostało to zarysowane w artykule Marty Rusek pt. Kwestia stylu. Refleksje o tożsamości polonisty $i$ stylach nauczania, określenie efektownie nie wiąże się tu z nastawieniem na nowość i fragmentaryzm. „Efektywnością” w tym wypadku byłaby taka forma prowadzenia zajęć, która zajmowałaby uczniów. Oczywiście, nie ma mowy o możliwości zdefiniowania takiego ,idealnego” modelu. Niełatwo sprawdzić, czy proces dydaktyczny jest efektowny, ale są pewne czynniki sugerujące, że uczniowie lubią sposób prowadzenia zajęć, np. wysoka frekwencja, aktywność. Zob. M. Rusek: Kwestia stylu. Refleksje o tożsamości polonisty i stylach nauczania. W: Doskonalenie warsztatu nauczyciela polonisty. Red. A. Janus-Sitarz. Kraków 2005, s. $205-225$. 
wo określonych wymogów „efektowności” ${ }^{24}$, widzowie nie są zainteresowani jego dziełem. Brak sukcesu komercyjnego i artystycznego skutkuje w dalszej perspektywie utratą zaufania — zarówno publiczności, producentów, jak i aktorów.

\section{Nauczyciel aktorem}

Jedną z najbardziej znanych w kulturze postaci nauczyciela, który efektywnie i efektownie posługuje się w swoim zawodzie aktorstwem, jest John Keating — bohater powieści Nancy H. Kleinbaum Stowarzyszenie Umartych Poetów ${ }^{25}$, brawurowo zagrany przez Robina Williamsa w adaptacji filmowej autorstwa Petera Weira z 1989 roku $^{26}$. Keating jest nowym nauczycielem języka angielskiego w renomowanej szkole - Akademii Weltona. Mężczyzna od razu wkupuje się w łaski swoich uczniów, stając się dla nich z czasem wielkim autorytetem. Przyczyną tego stanu rzeczy jest bez wątpienia ogromna charyzma, którą nauczyciel jest obdarzony i która pozwala mu na tworzenie przemyślanych, inteligentnych miniperformansów w ramach swoich zajęć. Na pierwszej prowadzonej lekcji z zespołem klasowym, wokół którego zogniskowana jest filmowa akcja, zamiast przywitać się z grupą, wychodzi z sali, pogwizdując. Tym samym zaprasza zdezorientowanych uczniów do spaceru po budynku szkolnym. Prośba ta budzi oczywiście duże zainteresowanie zespołu klasowego, który nie przywykł do tego typu zachowań w nieco skostniałej już placówce dydaktycznej. Należy jednak zwrócić uwagę, że nie sam gest wyjścia z sali jest tu nietypowy. To, co zdumiewa uczniów, to sposób podania informacji o zmianie miejsca zajęć — doskonały „występ” Keatinga wcielającego się w kogoś, kto nie będzie konwencjonalnym belfrem nauczającym ex cathedra. W efekcie odegranej przez siebie nonszalancji staje się on dla swoich widzów kimś zupełnie nieprzystającym do środowiska, w którym pracuje. Umiejętnościami aktorskimi Keating sprawia, że uczniowie (a widzowie filmu Weira razem z nimi) przestają mieć świadomość, że uczestniczą w procesie edukacyjnym, lecz interesuje ich przede wszystkim dalsza akcja - to, co za chwilę zrobi ten ekstrawagancki mężczyzna. Keating wykorzystuje pogwizdywanie jako „wędkę” mającą zachęcić uczniów do dalszego podążania jego śladem. Świadomie przyjmuje określoną

${ }^{24} \mathrm{Na}$ „efektowność” filmu bądź spektaklu wpływ ma wiele elementów, które budują jego jakość artystyczną lub rozrywkową (reżyseria, gra aktorska, muzyka, scenografia, temat, przesłanie itd.).

${ }^{25}$ N.H. Klein baum: Stowarzyszenie umartych poetów. Poznań 2012.

${ }^{26}$ Zob. Stowarzyszenie umarlych poetów (Dead Poets Society)... 
konwencję, licząc na właściwe reakcje uczniowskie. Przypuszczać można, że gdyby chłopcy z Akademii Weltona zareagowali niechętnie na propozycję wzięcia udziału w ,spacerze/performansie”, Keating, wbrew pozorom, nie znalazłby się na przegranej pozycji. Efektowna nietypowość gwarantuje wygenerowanie w zespole klasowym emocji, które „kierują uwagą" ${ }^{27}$ i są kluczem do efektywnego przyswajania wiedzy.

Niedługo po opuszczeniu sali Keating za pomocą swoich umiejętności aktorskich przeprowadza uczniów przez kolejne ogniwa lekcyjne. Seria przywołanych utworów i kontekstów mogłaby być elementem wykładu, pogadanki czy dyskusji, jest jednak mistrzowsko wyreżyserowanym spektaklem. Aby właściwie opisać elementy reżyserskiej pracy Keatinga wykorzystane w omawianej scenie, warto odwołać się do słownika terminów filmowych. Na początku „popisu”, przywołując utwory poetyckie Whitmana, Herricka, a także swoje doświadczenia młodzieńcze, tworzy on narrację przywodzącą na myśl filmowy plan ogólny. Motyw przemijania zostaje przedstawiony słuchaczom w bardzo szerokim kontekście (młodość Keatinga, wiersz Herricka Do panien, aby czasu próżno nie trwoniły, znaczenie hasła carpe diem), staje się tłem tematu lekcji, dzięki któremu zyska konkretyzację. Prosząc uczniów o przyjrzenie się twarzom nieżyjących już absolwentów, jak za pomocą filmowego zbliżenia Keating przenosi uwagę słuchaczy z planu ogólnego na konkret. Prosi uczniów o zrobienie kilku kroków naprzód, zbliżenie się do starego zdjęcia. Ta specyficznie podana ${ }^{28}$ prośba o wgląd w sfotografowane twarze absolwentów Akademii Weltona generuje niebywałe skupienie wśród jego widzów. Kluczowa jest puenta tej sceny - osobliwie wyszeptane przez Keatinga hasło carpe diem i zbiorowa konsternacja klasy. W następstwie efektu immersji — „wciągnięcia” w profesorską narrację i sposobu artykulacji mającego imitować „głos z zaświatów” niektórzy ze słuchaczy biorą tę łacińską paremię za rzeczywistą wiadomość od starszych pokoleń. Trudno nie przypuszczać, że nawet później, kiedy wszyscy uczniowie zdali sobie sprawę z charakteru sytuacji — wyreżyserowanej zgrywy Keatinga, przynajmniej kilku z nich doświadczyło czegoś, co można przyrównać do Arystotelesowskiego katharsis. W taki sposób, z pomocą aktorskich i reżyserskich umiejętności nauczyciela, abstrakcyjna opowieść o pełnych marzeń równolatkach stała się dla słuchaczy historią osobistą.

Omówiona perspektywa, rzecz jasna, ogniskuje się przede wszystkim wokół aktorskich elementów pracy nauczyciela. Gdyby John Keating nie dysponował odpowiednią charyzmą, dykcją czy postawą, nie byłoby mowy o potencjalnym

27 A. Dąbrowski: Wplyw emocji na poznawanie. „Przegląd Filozoficzny. Nowa Seria” 2012, nr 3 (83), s. 327.

${ }^{28}$ Keating wykorzystuje swoje umiejętności retoryczne (przypomina słuchaczom, że śmierć jest nieunikniona, podkreśla podobieństwa między pokoleniami uczniów) i aktorskie „sztuczki” (ścisza głos). 
efekcie katharsis. Jednak oprócz wyżej wymienionych, unaocznia się w tej scenie jeden z najważniejszych aspektów pracy pedagogicznej, który pokrywa się z profesją reżysera - kierowanie uwagą widzów. W teatrze bądź kinie za wiarygodnością aktora, który opowiada historię, stoi wiele innych osób — od inspicjentów, poprzez kostiumografów, charakteryzatorów, po operatora i reżysera. W szkole nauczyciel jest skazany na samotność — musi reżyserować samego siebie.

\section{Nauczyciel reżyserem}

Najbardziej powszechna jest jednak okoliczność lekcyjna, w trakcie której nauczyciel albo jest tylko jednym z aktorów, albo w ogóle skupia się wyłącznie na kierowaniu grupą - reżyserowaniu. W ramach analizy tej sytuacji warto zająć się trzema zagadnieniami dotyczącymi obu profesji — obsadą, pracą na planie (w próbach) i efektem finalnym pracy.

Andrzej Wajda, analizując swój proces twórczy, skonstatował kiedyś, że „są dwa momenty, w których reżyser musi mieć natchnienie — kiedy wybiera temat i kiedy wybiera aktorów. Reszta jest wykonaniem i przypomina piłowanie laubzegą" 29 . Z wyjątkiem ewentualnych nacisków producenckich, a także innych, niezależnych od decyzji artystycznych przyczyn, z reguły to reżyser wybiera obsadę $e^{30}$. Aktorzy, z którymi współpracuje, to grupa osób chętnych do współdziałania, jeżeli nie z powodów wysublimowanych, to przynajmniej finansowych. W realiach szkolnych nauczyciel otrzymuje grupę do pracy niezależnie od swojej woli, a poziom zaangażowania tego kolektywu w kooperację jest dużo mniej przewidywalny i sterowalny niż w wypadku artystów. System współpracy nauczyciela z uczniami można porównać do produkcji serialowych „tasiemców”, gdzie do utworzonego zespołu aktorskiego dołącza raz na jakiś czas inny reżyser, z którym grupa nawiązuje relację będącą wypadkową składników, jakie wynikają z osobistych preferencji.

W edukacji szkolnej okoliczności pozadydaktyczne są marginalizowane, informacje na temat dotychczasowych osiągnięć i życia osobistego nauczycieli nie mają dla uczniów większego znaczenia - funkcjonują jedynie w społeczności szkolnej jako ciekawostka. Niezwykle rzadko się zdarza „nauczyciel celebryta”

${ }^{29}$ Cyt. za: R. Gliński: Między stowem a obrazem. Z notatnika reżysera. „Images” 2011, nr 15-16 (vol. 8), s. 136.

${ }^{30}$ Tak samo jest z tematem, którym się zajmuje. Analiza tego zagadnienia w ramach omawianego problemu byłaby z pewnością bardzo ciekawa, kwestia jest jednak na tyle złożona, że wymagałaby odrębnego artykułu. 
przyciągający na lekcje grono chcących z nim współdziałać słuchaczy ${ }^{31}$, uczniowie zresztą są pozbawieni możliwości wyboru swoich pedagogów, co wymaga od obu stron mocnego skoncentrowania się na procesie lekcyjnym (twórczym). Ów proces na swoim podstawowym poziomie nie różni się bardzo od współpracy na linii aktor — reżyser.

Wybitny twórca teatralny i pedagog Zygmunt Hübner w książce Sztuka reżyserii pisał:

Reżyser jest inspiratorem, musi zarażać swoją pasją, swoją wiarą w sens tego, co robi. Wpierw aktorów, następnie publiczność. Jakże mógłby tego dokonać, nie mając sam ani pasji, ani wiary? Jeśli nachodzą go wątpliwości - lepiej, jeśli nie zdradza się z nimi wobec aktorów. Kiedy przyjdzie mu do głowy: „Po co ja to robię?”, a za późno już, aby się wycofać, niech raczej idzie na wódkę, niż zwraca się z tym pytaniem do zespołu ${ }^{32}$.

Trudno się nie zgodzić, że zarówno reżyser, jak i nauczyciel powinni się charakteryzować wiarą w to, co robią. Brak przekonania o sensie swojej pracy naraża przedstawicieli obu profesji na niewiarygodność i skutkować musi utratą (jakże ważnego) autorytetu. Inną sprawą są jednak wątpliwości reżysera (nauczyciela) dotyczące konkretnych zagadnień w ramach rozmaitych działań ze współpracownikami (uczniami). Nie ulega wątpliwości, że kierowanie grupą generuje wiele sytuacji wymagających podejmowania ważkich decyzji. Czy ten, który raz za razem zmuszony jest uzgadniać, rozstrzygać, wyrokować, ma prawo do jawnego przyznania, że ,nie ma pojęcia”? XX- i XXI-wieczna historia polskiej praktyki reżyserskiej wyklarowała w ramach tego zagadnienia trzy odmienne strategie. Pierwszej z nich patronować może postać Romana Polańskiego, jako reżysera despoty, trzymającego pieczę nad najmniejszym szczegółem swojego przedsięwzięcia i niejednokrotnie traktującego aktora instrumentalnie. Ten typ pracy najlepiej charakteryzuje zdanie, które autor Noża w wodzie wypowiedział kiedyś podczas pracy na planie filmu Chinatown do aktorki Faye Dunaway: „Możesz się ze mną kłócić, Faye, lecz pamiętaj, że nie mogę się mylić. Jestem reżyserem"33. Ta wypowiedziana pewnie pół żartem, pół serio konstatacja tworzy wizerunek reżysera jako osoby genialnej, niedostępnej, przekonanej o swojej nieomylności. Druga strategia, pośrednia, charakteryzuje się ukrywaniem wątpliwości. Reżyser często czuje się zagubiony, nie jest pewny swoich decyzji, ale stara się to ukryć. Trudno ocenić, ilu twórców realizuje ten „program”,

${ }^{31}$ Takie sytuacje zdarzają się z większą częstotliwością w ramach dydaktyki szkół wyższych, gdzie kadra prowadząca zajęcia ma większą swobodę w doborze tematyki zajęć i indywidualizacji procesu dydaktycznego.

32 Z. Hübner: Sztuka reżyserii. Warszawa 1982, s. 67.

33 J. Szczerba: 28 ran Sharon Tate. „Gazeta Wyborcza” z 7.10.2009, s. 16. 
ponieważ w zawodzie, w którym ogromną wartość ma autorytet prowadzącego grupę, jego jawne przyznawanie się do niewiedzy musi być niesłychaną rzadkością, co nie znaczy, że deklaracje „reżyserskiego zbłądzenia” się nie zdarzają. Patronem trzeciej strategii współpracy między reżyserem i aktorami byłby z pewnością Andrzej Wajda, filmowiec znany z tego, że zawsze jasno komunikował swoją niewiedzę i wątpliwości. W jednym z wywiadów Jarzy Radziwiłowicz wspominał historię, gdy pod koniec pracy nad Człowiekiem z marmuru Wajda wpadł na pomysł nagrania improwizowanej sceny na gdańskim dworcu. Nie miał jednak na nią żadnego konkretnego pomysłu, do czego szybko ekipie się przyznał, a w ramach przeprosin zaprosił Radziwiłowicza i Jandę na kolację, postawił wódkę i przeszedł ze swoimi aktorami na „ty”, sugerując, że po takiej kompromitacji nie ma innego wyjścia ${ }^{34}$. W każdej z tych grup znajdują się artyści uważani za wielkich, ale gdyby wczytać się w relacje i wywiady ze współpracownikami tych trzech grup reżyserów, jasne się staje, że im reżyser bardziej egocentryczny i bezwzględny, tym aktorzy bardziej do jego metod zdystansowani. Oczywiście, w wielu wypadkach reżyserska bezkompromisowość uznawana bywa za jedną z głównych przyczyn powstania wybitnego dzieła ${ }^{35}$. Wielu aktorów, na przykład współpracownicy Jerzego Jarockiego, podkreślało, że jego niepobłażliwy tryb pracy ich ukształtował. Elżbieta Konieczna, autorka książki o artyście, w rozmowie z Jolantą Ciosek konstatowała: „Wszyscy chcieli z nim pracować, bo doceniali jego geniusz i wiedzieli, że stoją przed potencjalnym sukcesem. Równocześnie określeń: potwór w pracy, tyran, terrorysta nie brakowało. Bali się go, nienawidzili i kochali zarazem" ${ }^{36}$. Niewątpliwie takie (nazwane kiedyś przez Konrada Swinarskiego, autora legendarnych Dziadów z krakowskiego Teatru Starego) ,nacinanie kory" ${ }^{37}$ aktorskiej prowadzi do wielu zdumiewających efektów, są jednak one często okupione rozmaitymi traumami.

${ }^{34}$ Wajda Making, Jerzy Radziwitowicz // Wajda Making odc. 2. https://www.youtube.com/ watch?v=dtrVVRCXlzY [data dostępu: 20.12.2019].

35 Tutaj można przywołać Jamesa Camerona, uznawanego w środowisku hollywoodzkim za reżysera-tyrana, który odbierając statuetkę Oscara za Titanica w 1998 roku, wykrzyknął: „Jestem królem świata!”, dając dowód swojego egocentryzmu. Jeden z największych wizjonerów współczesnego kina „podczas kręcenia Titanica [...] kazał Kate Winslet godzinami tkwić w lodowatej wodzie i pozwolił jej myśleć, że się topi, bo zależało mu na autentyzmie. Sam Worthington, który gra w Avatarze, dla autentyzmu oberwał od reżysera trzymetrową pałką z kauczuku. Z kolei podczas pracy nad Otchłanią Cameron oszczędzał czas, zabraniając aktorom chodzić do toalety. Mieli się załatwiać w wodzie, nie zdejmując kostiumów". Cyt. za: I. Nyc, A. Niedek: Tyran kina. „Wprost” 2009, nr 52/1405. https:/www.wprost.pl/tygodnik/182305/Tyran-kina.html [data dostępu: 13.01.2020].

36 J. Ciosek: Geniusz i demon. Bezwzględny. Tyran. Wrażliwiec. Jerzy Jarocki. „Polska Gazeta Krakowska" 2018, nr 238. http://www.e-teatr.pl/pl/artykuly/265422,druk.html [data dostępu: 20.01.2020].

${ }^{37}$ Termin użyty w książce J. Opalskiego pt. Rozmowy o Konradzie Swinarskim i „,Hamlecie”. Kraków 1988. 
Z uwagi na charakter omawianej profesji, reżysera z pewnością dużo bardziej będzie interesował aktor w wypracowanej na potrzeby tworzonego dzieła roli niż jego kondycja po realizacji filmu bądź spektaklu. Priorytetowym bowiem celem autora filmowego bądź teatralnego jest stworzenie docenionego dzieła sztuki, to, co się dzieje „wokół” i „wobec” procesu twórczego, ma działać na rzecz utworu, ewentualnie może być sympatycznym dodatkiem.

W odniesieniu do przedstawionej sytuacji szkolny system współpracy opiera się na zupełnie innej podstawie ${ }^{38}$. Otóż główną różnicą jest cel wspólnie realizowanych zadań. Teoretycznie proces dydaktyczny ma zakończyć się przyswojeniem przez uczniów określonej wiedzy bądź pozytywnie zdanym egzaminem. Ambicją nauczyciela jest jednak nie to, aby uczniowie ,zakuli, zdali, zapomnieli”, lecz nabyte umiejętności i informacje zostały z nimi dłużej. W przeciwieństwie do sukcesu artystycznego czy komercyjnego stworzonego przez reżysera dzieła sukces dydaktyczny jest nieuchwytny i nadal odraczany. Uczniowie przypominają sobie po wielu latach złote myśli ulubionych nauczycieli, wciąż wracają do nich sceny z życia szkolnego, wzory matematyczne i ,wałkowane” na lekcjach historyczne fakty.

Być może właśnie z powodu tego „trwałego efektu współpracy” nauczyciela z uczniem pedagogiczne maniery mogące generować wśród młodych ludzi traumy były piętnowane już od najdawniejszych epok. Erazm z Rotterdamu pisał:

Do pługa lepiej posłać takiego nauczyciela, który swym huczącym głosem, wystraszyłby nawet woły i osły. Jakże ty ośmielasz się uczyć drugich, ty, co sam niczego się nie nauczyłeś? Jak śmiesz, ty tępy kacie, bić batem młode istoty, zdolne, z uczciwej rodziny, które potrafisz raczej zabić, niż czegokolwiek wyuczyć! I to właśnie w budynku, który Grecy nazywali scholie, a Rzymianie ludus (szkoła), to jest miejscem zabawy i wytchnienia, ty posługujesz się swoim tyraństwem ${ }^{39}$.

Postawę egocentryczną w pracy dydaktycznej wykluczały także późniejsze pokolenia. Aleksander Kamiński postulował na przykład współpracę na zasadach demokratycznych. Pisał on:

${ }^{38}$ Warto nadmienić, że pomimo różnic w charakterze funkcjonowania w obu profesjach, typologia podobna do przedstawionej funkcjonowała już w teoriach pedagogicznych. Józef Kozłowski wyróżnił bowiem trzy typy nauczycieli: spolegliwych i sympatycznych — tych, którzy są bardzo lubiani przez swoich uczniów; nauczycieli obojętnych — niebędących w stanie pobudzić uczniów do żywej współpracy; nauczycieli surowych — stawiających jedynie wysokie wymagania, nieustannie strofujących i karcących. Bez wątpienia można odnieść to rozróżnienie do przedstawionej w niniejszym artykule typologii reżyserów. Por. J. Kozłowski: Analiza i ocena pracy nauczyciela. Warszawa 1966.

39 Cyt. za: S. Kot: Historia wychowania. Od starożytnej Grecji do połowy wieku XVIII. Warszawa 1996, s. 210. 
Podstawa demokratycznego kierownictwa wychowawczego, która stanowi fundament partnerskiej więzi z wychowankami, sprowadza się do tego w gruncie rzeczy, iż wychowawca nie stawia siebie ponad ani poza młodzieżą, lecz wśród niej. Jest czynny razem z młodymi i wśród młodych. Doradza - nie narzuca, inspiruje i sprawdza, a nie wykonuje czegoś za młodzież. Kontroluje, gdyż wie, że młodzież lubi być kontrolowana przez tych, którzy jej przewodzą ${ }^{40}$.

Chcąc odnieść do profesji reżysera to, co do tej pory zostało opisane w kontekście szkolnym, trzeba przyznać, że do iście „pedagogicznego podejścia” najbliżej takim artystom, jak Andrzej Wajda. Tym, którzy są wobec aktorów szczerzy i lojalni ${ }^{41}$. Nic dziwnego, że wobec tego reżysera tak często padało określenie „Nauczyciel” czy „Mistrz”.

\section{Nauczyciel mistrzem}

Rozważania te wskazują fakt ciągłego przenikania się profesji nauczyciela i reżysera. Oba zawody wymagają właściwego przygotowania i odpowiednich predyspozycji, ich istotą bowiem jest kontakt z drugim człowiekiem. Ów kontakt może być zadzierzgnięty w ramach konwencji spektaklu, gdzie nauczyciel reżyser jest narratorem i kieruje uwagą ucznia widza, a także może zostać nawiązany podczas wspólnej pracy, jako proces twórczy lub dydaktyczny. Pomimo to, że niejednokrotnie praca reżysera nauczyciela z aktorem uczniem ma konkretny finał (stworzenie wspólnego dzieła, efektywne zdanie egzaminu), jej efekty zostają ze współpracującymi dużo dłużej. Z tego powodu w obu zawodach szczególnej atencji wymaga od reżysera i nauczyciela proces kooperacji, w ramach którego prowadzący grupę może stać się dla jej członków kimś więcej niż tylko „,dobrym opowiadaczem historii” czy „edukatorem”.

W 2019 roku na krakowskim festiwalu filmowym Mastercard OFF Camera odbyło się spotkanie z młodą reżyserką Jagodą Szelc z okazji jej najnowsze-

${ }^{40}$ Cyt. za: B. Śliwerski: Współczesne teorie i nurty wychowania. Kraków 2001, s. 87.

${ }^{41}$ W tym miejscu warto przywołać słowa Stanisława Bortnowskiego, który rozpatrywał kwestie nauczycielskiej szczerości, odwołując się do swojej własnej niemocy: „Czy moje pamięciowe niedowłady miałem ujawniać uczniom? Biczować się, przyznawać do nieuctwa? Czasami, tylko czasami to czyniłem. Reguła postępowania była inna: jeżeli na przykład zadałem wiersz do nauczenia się na pamięć, sam starałem się go opanować. Że czegoś ze spraw tego świata, a także literatury nie wiem, to oczywiste, to nie poniża mojego autorytetu, ale że nie umiem sobie z tym poradzić — tego nie mogę im powiedzieć. Zniszczą mnie!”. S. Bortnowski: Przewodnik po sztuce uczenia literatury..., s. 123. 
go filmu Monument, będącego dyplomowym projektem studentów kończących naukę w łódzkiej Filmówce. Na spotkanie przybyli również występujący we wspomnianym obrazie aktorzy, dla których film ten był pożegnaniem ze szkołą i rodzajem specyficznej pamiątki ze studiów. Przyznali oni, że podeszli do współpracy z Jagodą Szelc z rezerwą, ponieważ szkolne doświadczenia nauczyły ich, że pedagogom i „ludziom z branży” nie można zbytnio zaufać. Obawy okazały się płonne. Jak przyznali występujący, praca nad filmową opowieścią o studentach, którzy przyjeżdżają na praktyki do prowincjonalnego hotelu, okazała się dla nich czymś niezwykle ważnym, wyzwalającym i dającym odwagę do dalszego funkcjonowania w zawodzie. Szelc stała się dla nich nauczycielem, ale także Mistrzem ${ }^{42}$.

$\mathrm{Z}$ całą pewnością ogromny wpływ na taką ocenę musiał mieć sposób pracy reżyserki ${ }^{43}$. Wypowiadając się $w$ rozmaitych wywiadach na temat swojej metody twórczej, autorka Monumentu podkreśla zwykle, że w kontakcie z ekipą filmową przykłada ogromną wagę do zespołowości i wzajemnej lojalności ${ }^{44}$. Efektywne współdziałanie opierałoby się więc nie tylko na rozwiązywaniu bieżących problemów, ale również na planowaniu pracy, która uwzględnia dynamikę i możliwości grupy. W kontekście pedagogicznym tę kwestię podejmowały i lansowały dwa tomy Dziecka w świecie współdziałania pod redakcją Bronisławy Dymary ${ }^{45}$, a także artykuł Anny Biernackiej Sposoby angażowania uczniów w proces dydaktyczny, czyli o planowaniu ${ }^{46}$. Wspomniany sposób kooperacji

${ }^{42}$ Definicję mistrzostwa w kontekście pedagogicznym formułował między innymi Jan Władysław Dawid, przekonując, że nauczyciela-mistrza cechuje ,pragnienie i dążenie do tego, aby tak prowadzić swego wychowanka, by ten go przewyższył i stał się od niego doskonalszy”. $\mathrm{K}$. Dormus: $O$ „duszy nauczycielstwa” $w$ świetle wspomnień gimnazjalistów galicyjskich..., s. 123.

${ }^{43}$ Relacja między młodymi aktorami a artystką filmową budzi skojarzenia z więzią między Janem Błońskim i Kazimierzem Wyką, jaką ten pierwszy opisał w artykule Tajemnica Wyki: „[Mistrz prowadzi] w takie sfery wiedzy, myślenia, jakich my nawet nie podejrzewamy, ale które gdzieś istnieją na pewno. Daje to uczniowi rozkoszne poczucie bezpieczeństwa. Mistrzem jest ten, kto potrafi wmówić, że za nim stoi wielka, tajemnicza wiedza, która wszystko wyjaśnia, a on ma do tej wiedzy klucz”. J. Błoński: Tajemnica Wyki. W: Błoński przekorny. Dziennik. Wywiady. Oprac. M. Zaczyński. Kraków 2011, s. 252.

44 „To jest mój film, ale bez dyżurnych na planie bym go nie zrobiła. Chciałabym, żeby to się zmieniło, że buduje się schemat piramidalny, jak w korporacjach, z jedną najważniejszą osobą u szczytu. To jest nieprawdziwy i niedobry układ. Ja pracuję horyzontalnie, czyli falangowo. Jestem w centrum, to jest mój film, dałam mu zapłon, ale wszystkie kolejne piony odchodzą ode mnie aż do ostatniego pionu produkcji, który zamyka kształt filmu. Który pion ma być najważniejszy, skoro one wszystkie zlewają się w jedno? Żaden”. M. Kempisty, J. Szelc: , Ludzie boją się, że im kradnę rozkosz”. https://www.filmawka.pl/jagoda-szelc/ [data dostępu: 20.01.2020].

${ }^{45}$ Dziecko w świecie wspótdziałania. Red. B. Dymara. Kraków 2001.

${ }^{46}$ A. Biernacka: Sposoby angażowania uczniów w proces dydaktyczny, czyli o planowaпіи..., s. 101-119. 
jest również spójny z myślą pedagogiczną, jaką propagowała przed laty Maria Grzegorzewska. Postulując relację opartą na życzliwości, a także wspólnocie nauczyciela z uczniami, badaczka pisała:

Radość z wyników choćby najdrobniejszych, ale dobrych w pracy, radość realizowania jakiejś myśli swojej, radość budzenia inicjatywy i zapału innych, radość budzącej się do życia coraz wyraźniej całej gromady i poszczególnych jednostek, radość życzliwej i skutecznej pomocy w procesie wrastania wychowanków w kulturę, w zdobywanie wiedzy, pogłębianie się, słowem stawanie się Człowiekiem wyjaśnia im wartość życia własnego ${ }^{47}$.

Nie ulega wątpliwości, że zarówno nauczyciel, jak i reżyser, wprowadzając w życie owe rozpoznania Grzegorzewskiej albo tryb pracy Szelc, w trudnych chwilach będzie miał okazję, tak jak John Keating, usłyszeć od swoich aktorów uczniów frazę: „O Kapitanie! Mój Kapitanie!”, a po latach nawet może ktoś nazwie go swoim „Mistrzem”.

\section{Bibliografia}

Banach C.: Nauczyciel. W: Encyklopedia pedagogiczna XXI wieku. T. 3. Red. T. Pilch. Warszawa 2004.

Biernacka A.: Sposoby angażowania uczniów w proces dydaktyczny, czyli o planowaniu. W: Doskonalenie warsztatu nauczyciela polonisty. Red. A. Janus-Sitarz. Kraków 2005.

Błoński przekorny. Dziennik. Wywiady. Oprac. M. Zaczyński. Kraków 2011.

Bortnowski S.: Przewodnik po sztuce uczenia literatury. Warszawa 2005.

Buchcic E.: Czynniki warunkujace profesjonalizm nauczyciela. „Prace Naukowe Akademii im. Jana Długosza w Częstochowie" 2016, nr 2 (t. 25).

Dąbrowski A.: Wpływ emocji na poznawanie. „Przegląd Filozoficzny. Nowa Seria” 2012, nr 3 (83).

Dormus K.: $O$ „,duszy nauczycielstwa” w świetle wspomnień gimnazjalistów galicyjskich. W: Wychowawca, nauczyciel, mistrz. O potrzebie mądrości, autorytetu i cnoty. Red. B. Jędrychowska. Wrocław 2017.

Dziecko w świecie współdziałania. Red. B. Dymara. Kraków 2001.

Gliński R.: Między stowem a obrazem. Z notatnika reżysera. „Images” 2011, nr 15-16 (vol. 8).

Grzegorzewska M.: Listy do młodego nauczyciela. Warszawa 1947.

Grzegorzewska M.: Listy do młodego nauczyciela. Warszawa 1996.

Hübner Z.: Sztuka reżyserii. Warszawa 1982.

Janowski A.: Uczeń w teatrze życia szkolnego. Warszawa 1995.

Kleinbaum N.H.: Stowarzyszenie umartych poetów. Poznań 2012.

${ }^{47}$ M. Grzegorzewska: Listy do młodego nauczyciela. Warszawa 1996, s. 35. 
Klemensiewicz Z.: Sposoby wprowadzenia, opracowania $i$ utrwalenia nowego materiatu. W: Wybór prac z metodyki nauczania języka polskiego. Red. B. Wieczorkiewicz. Warszawa 1964.

Kot S.: Historia wychowania. Od starożytnej Grecji do połowy wieku XVIII. Warszawa 1996.

Kozłowski J.: Analiza i ocena pracy nauczyciela. Warszawa 1966.

Mikiewicz P.: Nauczyciel jako istotny aktor społecznego świata szkoły. W: Nauczyciel: misja czy zawód? Spoleczne i profesjonalne aspekty roli. Red. P. Rudnicki, B. Kutrowska, M. Nowak-Dziemianowicz. Wrocław 2008.

Nowakowski J.: Moment twórczy w nauczaniu literatury. „Dydaktyka Literatury” 1982, t. 5.

Opalski J.: Rozmowy o Konradzie Swinarskim i „Hamlecie”. Kraków 1988.

Rusek M.: Kwestia stylu. Refleksje o tożsamości polonisty i stylach nauczania. W: Doskonalenie warsztatu nauczyciela polonisty. Red. A. Janus-Sitarz. Kraków 2005.

Stowarzyszenie umarlych poetów (Dead Poets Society). Reż. P. Weir. USA 1989.

Szczerba J.: 28 ran Sharon Tate. „Gazeta Wyborcza” z 7.10.2009.

Szuman S.: Talent pedagogiczny. W: Osobowość nauczyciela. Red. W. Okoń. Warszawa 1962.

Śliwerski B.: Współczesne teorie i nurty wychowania. Kraków 2001.

Wróblewski J.: Reżyserzy. Inowrocław 2013.

\section{Źródła internetowe}

Ciosek J.: Geniusz i demon. Bezwzględny. Tyran. Wrażliwiec. Jerzy Jarocki. „Polska Gazeta Krakowska" 2018, nr 238. http://www.e-teatr.pl/pl/artykuly/265422,druk.html [data dostępu: 20.01.2020].

Górna M.: Czekacie na nowego Tarantino? Ten facet z wypożyczalni VHS zmienit kino. I wielu próbuje go naśladować. „Gazeta Wyborcza” z 16.08.2019. https://wyborcza.p1/7,101707,25081465, byc-jak-quentin-tarantino-czyli-kto-tu-kopiuje-kogo-jak-facet.html [data dostępu: 13.01.2020].

Kempisty M., Szelc J.: Jagoda Szelc: „Ludzie boja się, że im kradnę rozkosz”. https://www. filmawka.pl/jagoda-szelc/ [data dostępu: 20.01.2020].

Makowska J., Knittel T.: Roman Polański. Rozmowy poszczególne. https://ninateka.pl/film/ roman-polanski-cz1 [data dostępu: 5.01.2020].

Nyc I., Niedek A.: Tyran kina. „Wprost” 2009, nr 52/1405. https://www.wprost.pl/tygodnik/ 182305/Tyran-kina.html [data dostępu: 13.01.2020].

Wajda Making, Jerzy Radziwiłowicz // Wajda Making odc. 2. https://www.youtube.com/watch?v= dtrVVRCXlzY [data dostępu: 20.12.2019].

Wielki stownik języka polskiego. Red. P. Żmigrodzki. https://www.wsjp.pl/ [data dostępu: 3.01.2020]. 